\title{
$\beta$-ecdysone content and antioxidant capacity in different organs of Brazilian ginseng
}

\author{
Lucas Dutra Zani da Silva Souza ${ }^{1}$ (i) Stéphane Raquel Almeida Velande da Fonseca ${ }^{2}$ (D) \\ Ariana Ferrari ${ }^{3}$ Daniele Fernanda Felipe ${ }^{3 *} \mathbb{D}$
}

'Programa de Pós-graduação em Tecnologias Limpas, Centro Universitário de Maringá (UNICESUMAR), Maringá, PR, Brasil. ${ }^{2}$ Programa de Pós-graduação em Ciência, Tecnologia e Segurança Alimentar, Centro Universitário de Maringá (UNICESUMAR), Maringá, PR, Brasil. ${ }^{3}$ Programa de Pós-graduação em Tecnologias Limpas, Centro Universitário de Maringá (UNICESUMAR), Instituto Cesumar de Ciência Tecnologia e Inovação (ICETI), 87050-900, Maringá, PR, Brasil. E-mail: daniele.felipe@unicesumar.edu.br. "Corresponding author.

\begin{abstract}
Plants that contain antioxidant compounds have attracted increasing interest for their vital role in the attenuation of oxidative damage caused by free radicals and in the treatment of various diseases. The present study investigated the $\beta$-ecdysone content and the antioxidant activity of Brazilian ginseng (Pfaffia glomerata) extracts obtained from inflorescences, stems, and roots. The P. glomerata extracts were tested for antioxidant activity using the 2,2-diphenyl-1-picrylhydrazyl (DPPH) radical scavenging method, $\beta$-carotene bleaching test, and phosphomolybdenum method. The $\beta$-ecdysone content of $P$. glomerata extracts was measured by high-performance liquid chromatography (HPLC). The P. glomerata inflorescences showed the strongest DPPH radical scavenging activity and the strongest antioxidant activity in the $\beta$-carotene bleaching assay and phosphomolybdenum test. The roots showed the lowest antioxidant capacity in all of the assays. The concentration of $\beta$-ecdysone in the plant organs followed the following decreasing order: inflorescences $>$ stems $>$ roots. The present study showed that P. glomerata inflorescence extract had high antioxidant capacity that could be attributed to the presence of $\beta$-ecdysone.
\end{abstract}

Key words: Pfaffia glomerata, $\beta$-ecdysone, scavenging activity methods.

Teor de $\beta$-ecdisona e capacidade antioxidante em diferentes órgãos de ginseng brasileiro

RESUMO: Plantas que contêm compostos antioxidantes têm atraído interesse crescente por seu papel fundamental na atenuação de danos oxidativos causados pelos radicais livres e no tratamento de várias doenças. O presente estudo investigou o conteúdo de $\beta$-ecdysone e a atividade antioxidante de extratos de ginseng brasileiro (Pfaffia glomerata) obtidos a partir das inflorescências, caules e raizes. Os extratos de Pfaffia glomerata foram testados para atividade antioxidante usando o método sequestrante do radical 2,2-difenil-1-picrilhidrazil (DPPH), sistema modelo $\beta$-caroteno-linoleato e método de fosfomolibdênio. O conteúdo de $\beta$-ecdisona dos extratos de P. glomerata foi medido por cromatografia líquida de alta eficência (CLAE). As inflorescências de P. glomerata mostraram a maior atividade sequestrante de radical $D P P H$ e a maior atividade antioxidante no ensaio $\beta$-caroteno-linoleato e no teste de fosfomolibdênio. As raizes mostraram a menor capacidade antioxidante em todos os ensaios. A concentração de $\beta$-ecdisona nos órgãos da planta seguiu a seguinte ordem decrescente: inflorescências $>$ caules $>$ raízes. Os resultados indicaram uma correlação positiva entre conteúdo de $\beta$-ecdisona e atividade sequestrante de radical DPPH. $O$ presente estudo mostrou que o extrato das inflorescências de P. glomerata teve alta atividade antioxidante que poderia ser atribuída à presença de $\beta$-ecdisona.

Palavras-chave: Pfaffia glomerata, $\beta$-ecdisona, métodos de atividade sequestrante.

\section{INTRODUCTION}

The plants are considered a major source of natural antioxidants that can produce significant effects in the treatment of various diseases (SHOKRI et al., 2018). The natural antioxidants can protect the human body from free radicals and retard the progression of many chronic diseases (ADWAS et al., 2019). These natural antioxidants in health products are being assessed by the food, cosmetics and pharmaceutical industries (KUSUMAWATI \& INDRAYANTO, 2013; FIERASCU et al., 2019).
Pfaffia glomerata (Spreng.) Pedersen (Amaranthaceae), traditionally known as Brazilian ginseng, is a Brazilian medicinal plant of great economic interest because of its popularity in Brazil and its potential for exportation (NASCIMENTO et al., 2007). It has promising applications in both phytotherapy and phytomedicine (SALDANHA et al., 2013). The extract of Pfaffia glomerata roots has shown several biological properties, such as gastroprotective effects (FREITAS et al., 2004), leishmanicidal potential (TULMANN NETO et al., 
2005), antiinflammatory activity, and analgesic effect (TULMANN NETO et al., 2004). Moreover, studies have reported that the extract of Pfaffia glomerata roots has antioxidant activity (DANIEL et al., 2005; LEAL et al., 2010; BATISTA et al., 2019).

Several important compounds have been isolated and identified from roots of $P$. glomerata, such as glomeric acid (a triterpenoid) and pfameric acid (a nortriterpenoid), noroleanane-type triterpenes and oleanane-type triterpenes, together with ecdysterone ( $\beta$-ecdysone), rubrosterone, oleanolic acid, and $\beta$-glucopyranosyl oleanolate (SHIOBARA et al., 1993; HAN et al., 2018). $\beta$-ecdysone (20-hydroxyecdysone) is a relevant marker compound in the extractive solution from roots of $P$. glomerata (ZIMMER et al., 2006). Previous studies have confirmed the presence of $\beta$-ecdysone in all of the major organs of $P$. glomerata, such as roots (FREITAS et al., 2004; LEAL et al., 2010), stems, and inflorescences (SERRA et al., 2012). $\beta$-ecdysone is a secondary metabolite with biotechnological, pharmacological, medical, and agrochemical applicability (FELIPE et al., 2019). Researchers have reported the antioxidant activity of this compound (DANIEL et al., 2005; LAFONT \& DINAN, 2003; BATISTA et al., 2019). NSIMBA et al., (2008) showed that all of the isolated ecdysteroids in their study, including $\beta$-ecdysone, inhibited collagenase and the 2,2-diphenyl-1-picrylhydrazyl (DPPH) radical.

Considering the identification of $\beta$-ecdysone in $P$. glomerata inflorescences, stems, and roots (SERRA et al., 2012) and the antioxidant activity of $\beta$ -ecdysone (DANIEL et al., 2005; NSIMBA et al., 2008), all of the major organs of $P$. glomerata appear to be sources of natural antioxidants. Although considerable investigations have been performed on the roots of $P$. glomerata to assess different activities, including antioxidant activity, scientific information about the antioxidant properties of other organs of this plant is still unavailable. This study aimed to evaluate the antioxidant activity of different organs of $P$. glomerata (the inflorescences, stems, and roots) to identify the plant part that has the highest antioxidant capacity.

\section{MATERIALS AND METHODS}

\section{Plant material}

Pfaffia glomerata was collected in Querência do Norte, Paraná, Brazil. The plant was collected and identified by Prof. Dra. Maria Salete Marchioretto. A voucher specimen (PACA 107100) was deposited at the Herbarium PACA at the
Universidade do Vale do Rio dos Sinos, Rio Grande do Sul, Brazil. The plant was dried in a circulating-air oven at $45{ }^{\circ} \mathrm{C}$. The inflorescences, stems, and roots of the plant were then separated, triturated in a knife mill, and stored.

\section{Preparation of Pfaffia glomerata extracts}

The extracts obtained from the different organs of $P$. glomerata were prepared using the Soxhlet method with ethanol: water $(9: 1 \mathrm{v} / \mathrm{v})$ as established by Serra et al. (2012). For the preparation of each extract, tissue samples of $10 \mathrm{~g}$ were used. The extracts were vacuum filtered with filter paper, and the organic solvent was removed under vacuum at $40{ }^{\circ} \mathrm{C}$ using a rotary evaporator and lyophilized. The extracts were stored at $4{ }^{\circ} \mathrm{C}$ until use.

\section{HPLC analysis of $\beta$-ecdysone content}

To quantify $\beta$-ecdysone in different organs of $P$. glomerata, we used the HPLC method that was developed and validated by SERRA et al. (2012). $P$. glomerata extracts obtained from the roots, stems, and inflorescences and standard $\beta$-ecdysone were dissolved in methanol at a concentration of $3000 \mu \mathrm{g} /$ $\mathrm{ml}$ in triplicate. The analyses were performed using a Shimadzu LC-10 liquid chromatograph equipped with a quaternary pump (LC-10 AT), manual injection valve (Rheodyne), $20 \mu$ loop, degasser (DGU-14A), thermostatted column compartment (CTO-10A), ultraviolet/visible spectrum detector (SPD-10A), and controlled by CLASS VP software. A Phenomenex ODS (C18) column $(5 \mu \mathrm{m}, 250.0$ $\times 4.6 \mathrm{~mm}$ ) maintained at $30{ }^{\circ} \mathrm{C}$ was used for the chromatographic analysis. The separation was performed in a gradient system using a mixture of methanol:water as the mobile phase. At time 0-5 $\mathrm{min}$, the methanol:water concentration ranged from 10:90 (v/v) to $70: 30(\mathrm{v} / \mathrm{v})$. At time 5-12 min, the methanol:water concentration remained at 70:30 $(\mathrm{v} / \mathrm{v})$. At time 12-15 $\mathrm{min}$, the methanol:water concentration ranged from 70:30 (v/v) to 100:0 $(\mathrm{v} / \mathrm{v})$. The detection wavelength was $245 \mathrm{~nm}$, and the flow rate was $1 \mathrm{ml} / \mathrm{min}$, with a run time of 15 min. The sample injection volume was $20 \mu \mathrm{l}$. The retention time for the $\beta$-ecdysone standard was used to identify the corresponding peak in the $P$. glomerata extracts. The data used for the statistical analysis were relative to the quantification of $\beta$-ecdysone calculated based on the value of the peak area using the following regression equation described by SERRA et al. (2012): $y=25847 x$ 218747 , where $y$ is the peak area of $\beta$-ecdysone, and $x$ is the concentration of $\beta$-ecdysone. 
Antioxidant activity of $P$. glomerata extracts

$D P P H$ free radical scavenging assay

The free radical scavenging activity of the extracts of $P$. glomerata was evaluated according to the method described by BRAND-WILLIAMS, CUVELIER \& BERSET (1995). A solution of DPPH $(0.87 \mathrm{mM})$ in methanol was prepared daily before use. The sample solutions of each extract were prepared from stock solutions at a concentration of $1000 \mu \mathrm{g} /$ $\mathrm{ml}$ in methanol. Dilutions were made to obtain concentrations within the linear range of each extract. The stock solution of the inflorescence extract was dissolved in methanol, yielding concentrations of 25 , $50,75,100,125$, and $150 \mu \mathrm{g} / \mathrm{ml}$. The stock solution of the stem extract yielded concentrations of 50, 100, $200,300,400$, and $500 \mu \mathrm{g} / \mathrm{ml}$. The stock solution of the root extract yielded concentrations of 500, 600, $700,800,900$, and $1000 \mu \mathrm{g} / \mathrm{ml}$.

An aliquot $(3 \mathrm{ml})$ of sample solution was mixed thoroughly with $300 \mu$ of DPPH solution and then left for $30 \mathrm{~min}$ at room temperature in the dark. The absorbance of the resulting solutions was measured at $517 \mathrm{~nm}$ against a blank (3 ml sample solution and $300 \mu \mathrm{l}$ methanol) using a spectrophotometer (Thermo Scientific, Evolution 60). Three replicates were made for each test sample. A methanolic solution that contained $3 \mathrm{ml}$ methanol and $300 \mu \mathrm{l}$ of the DPPH solution was used as a negative control. The methanolic solution of BHT (1$25 \mu \mathrm{g} / \mathrm{ml}$ ) was used as a positive control. The DPPH radical scavenging activity (\%) was calculated using the following equation described by SCHERER \& GODOY (2009):

Scavenging activity $(\%)=\left[\left(\mathrm{Abs}_{0}-\mathrm{Abs}_{1}\right) / \mathrm{Abs}_{0}\right] \times 100$ where $\mathrm{Abs}_{0}$ is the absorbance of the negative control, and $\mathrm{Abs}_{1}$ is the absorbance in the presence of the test compound (extract/BHT) at different concentrations. The scavenging ability of the extracts is expressed as the $\mathrm{IC}_{50}$ value, which is the concentration of the sample that is required to scavenge $50 \%$ of DPPH free radicals. The $\mathrm{IC}_{50}$ values were calculated using linear regression plots, in which the ordinate represents the scavenging activity (\%), and the abscissa represents the concentration of the tested extracts. The plant extracts were considered active with an $\mathrm{IC}_{50}<500$ $\mu \mathrm{g} / \mathrm{ml}$ (CAMPOS et al., 2003; SANTOS et al., 2010).

The ability of the extracts to scavenge DPPH radicals at a concentration of $300 \mu \mathrm{g} / \mathrm{ml}$ was then compared with the synthetic antioxidant BHT at the same concentration. The plant extracts were considered to have good antioxidant activity when the inhibition percentage of DPPH was $>50 \%$, as described by FAWOLE et al. (2012).

\section{$\beta$-carotene linoleate model system}

The antioxidant activity of the extracts, based on the $\beta$-carotene-linoleate model system, was determined according to the method of KUMARAN \& KARUNAKARAN (2006). A solution of $\beta$-carotene was prepared by dissolving $2 \mathrm{mg}$ $\beta$-carotene in $10 \mathrm{ml}$ chloroform. An aliquot $(2 \mathrm{ml})$ of this solution was transferred to a $100 \mathrm{ml}$ flask. After chloroform was evaporated at room temperature, 40 $\mu 1$ linoleic acid, $400 \mu 1$ Tween 80 emulsifier, and 100 $\mathrm{ml}$ aerated distilled water were added to the flask with vigorous shaking. Aliquots $(4.8 \mathrm{ml})$ of this emulsion were transferred to different test tubes that contained $0.2 \mathrm{ml}$ of the extracts at a concentration of $1000 \mu \mathrm{g} / \mathrm{ml}$. As soon as the emulsion was added to each tube, zero-time absorbance was measured at $470 \mathrm{~nm}$ using a spectrophotometer. The tubes were placed in a water bath at $50{ }^{\circ} \mathrm{C}$ for $2 \mathrm{~h}$. The tubes were then cooled, and absorbance was recorded. A blank, devoid of $\beta$-carotene, was prepared for background subtraction. The same procedure was repeated with the synthetic antioxidant BHT at the same concentration, which was used as a positive control. Antioxidant activity (\%) was determined in triplicate for each extract and positive control and calculated using the following equation:

Antioxidant activity $(\%)=(\beta$-carotene content after 2 $\mathrm{h}$ of assay / initial $\beta$-carotene content $) \times 100$

The plant extracts were considered to show weak, moderate, and strong antioxidant activity when the inhibition percentage of oxidation was $<50 \%$, between $50 \%$ and $70 \%$, and $>70 \%$, respectively, as described by MELO et al. (2008).

\section{Phosphomolybdenum method}

The total antioxidant capacity of the extracts was evaluated using the phosphomolybdenum method according to the procedure described by PRIETO et al. (1999). An aliquot $(0.3 \mathrm{ml})$ of each sample solution or ascorbic acid $(200 \mu \mathrm{g} / \mathrm{ml})$ was combined with $3 \mathrm{ml}$ of reagent solution $(0.6 \mathrm{M}$ sulfuric acid, $28 \mathrm{mM}$ sodium phosphate, and $4 \mathrm{mM}$ ammonium molybdate). A typical blank solution contained 3 $\mathrm{ml}$ of the reagent solution and $0.3 \mathrm{ml}$ methanol, the same solvent used for the sample. All of the tubes were capped and incubated in a boiling water bath at $95{ }^{\circ} \mathrm{C}$ for $90 \mathrm{~min}$. After the samples were cooled to room temperature, the absorbance of the solution of each sample was measured at $695 \mathrm{~nm}$ against the blank using a spectrophotometer. The experiment was performed in triplicate. The antioxidant capacity of each extract was calculated based on the relative antioxidant activity of the extract relative to the 
ascorbic acid standard using the following equation: $\%$ relative antioxidant activity $=\left[\left(\mathrm{Abs}_{1}-\mathrm{Abs}_{0}\right) /\right.$ $\left.\left(\mathrm{Abs}_{2}-\mathrm{Abs}_{0}\right)\right] \times 100$

where $\mathrm{Abs}_{1}$ is the absorbance of the extract, $\mathrm{Abs}_{0}$ is the absorbance of the blank, and $\mathrm{Abs}_{2}$ is the absorbance of ascorbic acid. The results are expressed as milligrams of ascorbic acid equivalents (mg AAE/g dry extract).

\section{Statistical analysis}

All of the experiments were performed at least in triplicate, and the results are expressed as mean \pm standard deviation (SD). The $\mathrm{IC}_{50}$ values were calculated using linear regression analysis. For the analysis of $\beta$-ecdysone and in the antioxidant assays, the data were compared using analysis of variance (ANOVA) followed by Tukey's test. Pearson correlation analysis was performed to determine the correlation between $\beta$-ecdysone content and the antioxidant activity of the extracts. The level of significance was set at 5\%, and differences were considered statistically significant at $P<0.05$. The statistical analysis was performed using GraphPad Prism v. 5.0 software (GraphPad, San Diego, CA, USA).

\section{RESULTS AND DISCUSSION}

\section{HPLC analysis of $\beta$-ecdysone content}

$\beta$-ecdysone is a major phytoecdysteroid that has been found in species of the genus Pfaffia
(IAREMA et al., 2012). It has received considerable attention because of its pharmacological and medicinal properties. Phytoecdysteroid content, including $\beta$-ecdysone, is generally low in plants (DINAN, $2001)$, but $P$. glomerata has a high concentration of $\beta$-ecdysone (FESTUCCI-BUSELLI et al., 2008a). The present results demonstrated that $\beta$-ecdysone is the major compound in $P$. glomerata inflorescences, stems and roots (Figure 1), as has been demonstred also by FESTUCCI-BUSELLI et al. (2008b) and SERRA et al. (2012).

Significant differences in the concentrations of $\beta$-ecdysone were found in these different organs of the plant (Table 1). The concentration of $\beta$-ecdysone in inflorescences $(91.35 \pm 0.65 \mu \mathrm{g} / \mathrm{ml})$ was significantly higher than in stems $(71.51 \pm 0.93 \mu \mathrm{g} / \mathrm{ml})$ and in roots $(48.57 \pm 0.32 \mu \mathrm{g} / \mathrm{ml})$.

These results corroborate the levels of $\beta$-ecdysone in different organs of $P$. glomerata reported by SERRA et al. (2012), who also found a higher $\beta$-ecdysone content in inflorescences than in stems and roots. In another study (FESTUCCI-BUSELLI et al., 2008b), the analysis of $\beta$-ecdysone in $P$. glomerata germplasm bank accessions demonstrated that $\beta$-ecdysone was constantly detected in flowers, roots, leaves, and stems, with the highest content in flowers. Stems had the lowest $\beta$-ecdysone content.

Several studies have evaluated the $\beta$-ecdysone content in roots of $P$. glomerata, being

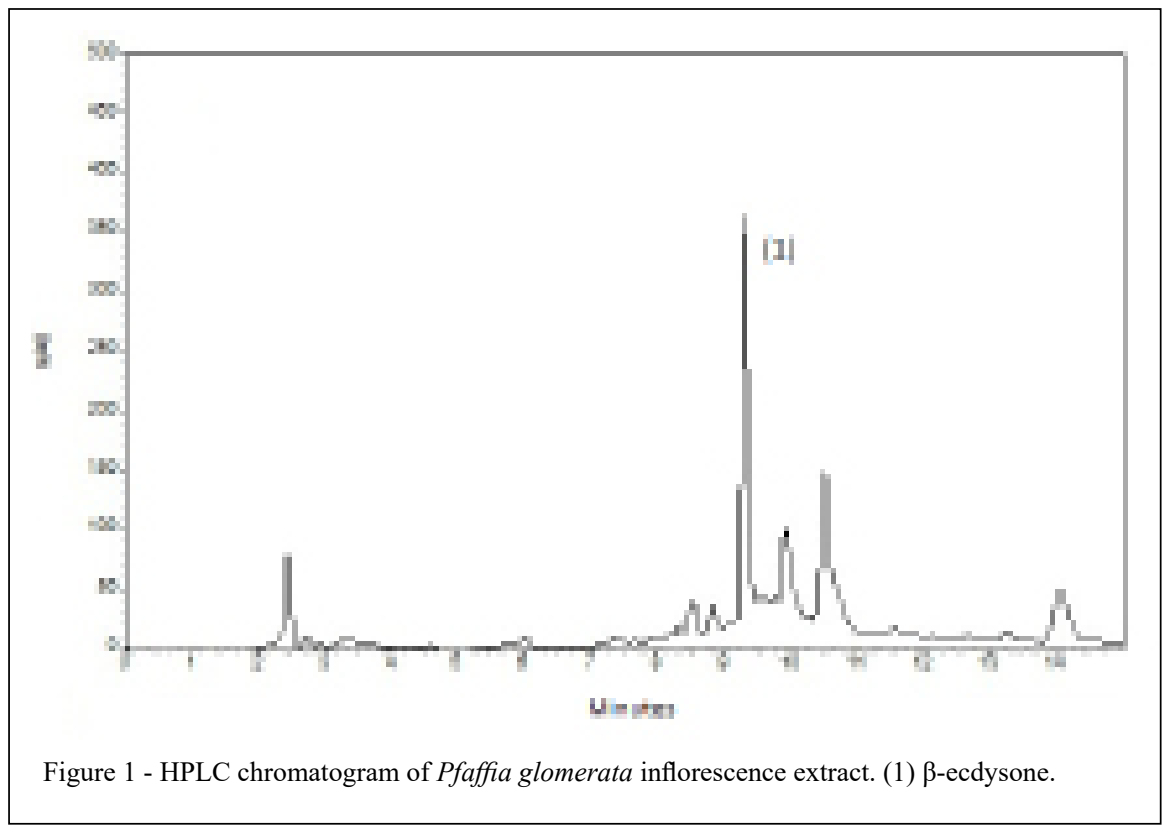

Ciência Rural, v.51, n.5, 2021. 
Table 1 - $\beta$-ecdysone content in P. glomerata inflorescences, stems, and roots.

\begin{tabular}{lc}
\hline Extract & $\beta$-ecdysone $(\mu \mathrm{g} / \mathrm{ml})$ \\
\hline Inflorescences & $91.35 \pm 0.65^{\mathrm{a}}$ \\
Stems & $71.51 \pm 0.93^{\mathrm{b}}$ \\
Roots & $48.57 \pm 0.32^{\mathrm{c}}$ \\
\hline
\end{tabular}

The data are expressed as the mean \pm standard deviation of triplicate measurements. Means with different letters (a-c) in the same column are significantly different $(P<0.05$, ANOVA).

the roots widely used in Brazilian traditional medicine (FREITAS et al., 2004; ZIMMER et al., 2006; FESTUCCI-BUSELLI et al., 2008a LEAL et al., 2010). However, in these previous studies, the $\beta$-ecdysone content in roots was lower than the content in inflorescences found in the present study. Moreover, $P$. glomerata produces a large quantity of inflorescences during almost all months of the year (LEITE et al., 2005). Thus, if P. glomerata inflorescences are a rich source of $\beta$-ecdysone and they are often discarded during plant processing, then their utilization should be encouraged.

Furthermore, according to FELIPE et al. (2014), P. glomerata inflorescences contain other important bioactive compounds in addition to $\beta$-ecdysone, such as flavonoid glycosides, quercetin-3-O-glucoside, kaempferol-3-O-glucoside and kaempferol-3-O-(6-pcoumaroyl)-glucoside, oleanane-type triterpenoid saponins such as ginsenoside Ro and chikusetsusaponin IV, in addition to oleanonic acid and gluconic acid.

\section{Antioxidant activity of $P$. glomerata extracts}

Antioxidant activity is measured indirectly by determining the inhibition rate of oxidation processes in the presence of an antioxidant (ANTOLOVICH et al., 2002). Various published methods are used to measure antioxidant capacity in vitro, but no single assay is capable of determining the total antioxidant ability of a studied sample. More than one method is needed to take into account the various modes of antioxidants' actions (ALAM et al., 2013). Thus, the antioxidant activity of $P$. glomerata extracts was evaluated using different assays.

\section{$D P P H$ free radical scavenging activity}

The DPPH stable free radical method is an easy, rapid, and sensitive way to determine the antioxidant activity of a specific compound or plant extract (KOLEVA et al., 2002). This assay is based on the principle that DPPH is able to decolorize in the presence of free radical scavengers (antioxidants). The color turns from purple to yellow when the odd electron of the DPPH radical becomes paired with hydrogen from an antioxidant to form the reduced DPPH-H. The degree of discoloration indicates the scavenging potential of the compounds in terms of hydrogen donating ability (OLAJUYIGBE; AFOLAYAN, 2011).

The ability of the $P$. glomerata extracts to scavenge DPPH radicals is presented in Table 2. A lower $\mathrm{IC}_{50}$ value indicates a stronger ability of the extract to act as a DPPH scavenger (TUNG et al., 2009). The extracts are considered active at an $\mathrm{IC}_{50}<500 \mu \mathrm{g} / \mathrm{ml}$ (CAMPOS et al., 2003; SANTOS et al., 2010). Thus, $P$. glomerata inflorescences $(120.23 \pm 2.51 \mu \mathrm{g} / \mathrm{ml})$ had the strongest scavenging activity, followed by stems $(297.54 \pm 1.94 \mu \mathrm{g} / \mathrm{ml})$. The roots $(1007.29 \pm 3.08 \mu \mathrm{g} / \mathrm{ml})$ had the weakest scavenging activity. A significant difference in $\mathrm{IC}_{50}$ values was found between the samples, including of the positive control BHT $(6.86 \pm 0.45 \mu \mathrm{g} / \mathrm{ml})$, which exhibited higher scavenging activity than the extracts. The degree of the radical scavenging

Table 2 - 2,2-diphenyl-1-picrylhydrazyl (DPPH) radical scavenging activity of Pfaffia glomerata extracts.

\begin{tabular}{lcr}
\hline Extract & IC50 $(\mu \mathrm{g} / \mathrm{ml})$ & $\%$ inhibition of DPPH at $300 \mu \mathrm{g} / \mathrm{ml}$ \\
\hline Inflorescences & $120.23 \pm 2.51 \mathrm{c}$ & $91.9 \pm 0.40 \mathrm{a}$ \\
Stems & $297.54 \pm 1.94 \mathrm{~b}$ & $52.8 \pm 1.17 \mathrm{~b}$ \\
Roots & $1007.29 \pm 3.08 \mathrm{a}$ & $11.5 \pm 0.85 \mathrm{c}$ \\
BHT $^{*}$ & $6.86 \pm 0.45 \mathrm{~d}$ & $92.2 \pm 0.56 \mathrm{a}$ \\
\hline
\end{tabular}

${ }^{*}$ Positive control. The data are expressed as the mean \pm standard deviation of triplicate measurements. Means with different letters (a-d) in the same column are significantly different $(P<0.05$, ANOVA). 
activity of the extracts was dependent on their concentration, with a considerable increase in activity as the concentration increased. At a concentration of $300 \mu \mathrm{g} / \mathrm{ml}$, the inflorescences reached the maximal scavenging activity $(91.9 \pm 0.40 \%)$, suggesting good DPPH radical scavenging ability, once that inhibition percentage of DPPH was above $50 \%$ (FAWOLE et al. 2012) and there was no significant difference compared with the control positive BHT (92.2 \pm $0.56 \%$ ). At the same concentration of $300 \mu \mathrm{g} / \mathrm{ml}$, the scavenging activity was significantly lower in the stems $(52.8 \pm 1.17 \%)$ and roots $(11.5 \pm 0.85 \%)$. This can be atributted to the lower $\beta$-ecdysone content in these organs of the plant, as discussed below.

The results presented in tables 1 and 2 show a positive correlation between higher $\beta$-ecdysone content in the extracts and stronger DPPH scavenging activity $(\mathrm{r}=0.947, p<0.01)$. This conclusion is also supported by published reports that demonstrated that $\beta$-ecdysone possesses strong DPPH scavenging ability, with an $\mathrm{IC}_{50}$ value of $3.8 \pm 1.6 \mu \mathrm{g} / \mathrm{ml}$ (NSIMBA et al., 2008), which is higher activity than the wellknown antioxidant compound BHT, which was used in our study. These researchers also reported that the antioxidant activity of $\beta$-ecdysone could be explained by the fact that its molecular structure has hydroxyl groups (hydrogen donor groups) and a methyl group (electron donor group) to its carbon skeleton. AWAH et al. (2012) reported a direct correlation between the degree of hydroxylation of the bioactive compounds and DPPH radical scavenging activity. Therefore, the strong DPPH scavenging activity of $P$. glomerata inflorescences (Table 2) may be attributed to the high $\beta$-ecdysone content (Table 1), although other antioxidant compounds may also be present in this part of the plant.

The present study compared the antioxidant properties of different organs of $P$. glomerata, namely the inflorescences, stems and roots. Previous studies had already reported the antioxidant activity of $P$. glomerata roots (DANIEL et al., 2005, LEAL et al., 2010). DANIEL et al. (2005) demonstrated the free radical scavenging activity of the butanolic fraction obtained from the roots, which was able to decrease thiobarbiturate reactive substances (TBARS) similarly to $\alpha$-tocopherol, which was used as a positive control.

\section{$\beta$-carotene linoleate model system}

The $\beta$-carotene bleaching model simulates the oxidation of membrane lipid components and measures antioxidant activity toward linoleic acid (FERREIRA et al., 2006). $\beta$-carotene in this model system undergoes rapid discoloration in the absence of an antioxidant. This is because of the coupled oxidation of $\beta$-carotene and linoleic acid, which generates free radicals (KUMARAN; KARUNAKARAN, 2006). Linoleic acid free radical reacts with unsaturated $\beta$-carotene molecules, resulting in the oxidation of $\beta$-carotene and subsequently the loss of its characteristic orange color. However, the presence of antioxidants can hinder the extent of $\beta$-carotene bleaching by neutralizing linoleate free radical and other free radicals formed in the system (JAYAPRAKASHA et al., 2001).

Table 3 presents the antioxidant activity of $P$. glomerata extracts measured by the $\beta$-carotene bleaching assay. In the present study, at a concentration of $1000 \mu \mathrm{g} / \mathrm{ml}$, the different organs of P. glomerata prevented the bleaching of $\beta$-carotene to different degrees. The antioxidant activity of the inflorescences $(50.4 \pm 1.45 \%)$ was significantly higher than the roots $(43.7 \pm 0.84 \%)$, but no significant difference was found compared with the stems $(47.9 \pm 0.91 \%)$. Although the antioxidant potential of different organs of $P$. glomerata was significantly lower than BHT $(98.1 \pm 0.55 \%)$, the results indicated that inflorescences and stems have moderate antioxidant activity, once that the inhibition of $\beta$-carotene bleaching was close to $50 \%$ (MELO et al., 2008). Leal et al. (2010) studied the antioxidant activity of $P$. glomerata roots using the $\beta$-carotene bleaching assay and extracts obtained under different extraction conditions. The extract obtained with low-pressure solvent extraction showed antioxidant activity close to $35 \%$, a lower value than the one found in our study.

\section{Phosphomolybdenum method}

The total antioxidant capacity assay is a spectroscopic method for the quantitative

Table 3 - Antioxidant activity of extracts of Pfaffia glomerata in the $\beta$-carotene-linoleate system.

\begin{tabular}{lc}
\hline Extract & Antioxidant activity (\%) at $1000 \mu \mathrm{g} / \mathrm{ml}$ \\
\hline Inflorescences & $50.4 \pm 1.45^{\mathrm{b}}$ \\
Stems & $47.9 \pm 0.91^{\mathrm{b}}$ \\
Roots & $43.7 \pm 0.84^{\mathrm{c}}$ \\
BHT $^{*}$ & $98.1 \pm 0.55^{\mathrm{a}}$ \\
\hline
\end{tabular}

*Positive control. The data are expressed as the mean \pm standard deviation of triplicate measurements. Means with different letters (a-c) in the same column are significantly different $(P<0.05$, ANOVA). 
determination of antioxidant capacity through the formation of the phosphomolybdenum complex. The assay is based on the reduction of Mo (VI) to Mo (V) by the sample analyte and subsequent formation of a green phosphate Mo (V) complex at acidic $\mathrm{pH}$ (ALAM et al., 2013). The reducing power of a compound is associated with electron donating capacity and serves as an indicator of antioxidant activity (SIDDHURAJU et al., 2002). The total antioxidant capacity of $P$. glomerata extracts is expressed as milligrams of ascorbic acid equivalents (mg AAE/g dry extract). All of the extracts exhibited some degree of antioxidant activity, with a significant difference in the values. The highest antioxidant capacity was exhibited by the inflorescences (167.8 $\pm 0.32 \mathrm{mg}$ AAE$/ \mathrm{g}$ dry extract), followed by the stems $(137.6 \pm 0.11 \mathrm{mg} \mathrm{AAE} / \mathrm{g}$ dry extract) and roots (123.2 $\pm 0.40 \mathrm{mg}$ AAE/g dry extract).

The antioxidant activity might be attributed to the presence of $\beta$-ecdysone in the different organs of $P$. glomerata, since this is the majority compound. However, other compounds could contribute to the antioxidant activity evaluated. For example, the compounds identified in the inflorescences by FELIPE et al. (2014), such as flavonoid glycosides, quercetin-3-O-glucoside, kaempferol-3-O-glucoside and kaempferol-3-O-(6- $p$ coumaroyl)-glucoside, have antioxidant activity, as described by ADWAS et al. (2019), who reports that flavonoids have been found to play important roles in the non-enzymatic protection against oxidative stress.

Oxidative stress causes irreversible damage in cellular macromolecules that leads to initiation of various diseases such as atherosclerosis, ischemic heart diseases, liver diseases, diabetes, initiation of carcinogenesis, and aging (ADWAS et al., 2019). The antioxidants are important species that possess the ability to protect the body from damage caused by free radicals induced oxidative stress (AZAB et al., 2017). Natural antioxidants inhibit of reactive oxygen species production and scavenging of free radicals (AZAB et al., 2017; ADWAS et al., 2019). Thus, as the $P$. glomerata inflorescence extract is a source of antioxidants, it has potential for the prevention of aging and diseases associated with oxidative stress.

\section{CONCLUSION}

The present study demonstrates that the $P$. glomerata inflorescences had a higher content of $\beta$-ecdysone and exhibited significant antioxidant capacity compared with the stems and roots. $\beta$-ecdysone may be responsible for the antioxidant activity observed for the different organs of the plant.

\section{ACKNOWLEDGEMENTS}

The authors thank to the Coordenação de Aperfeiçoamento de Pessoal de Nível Superior (CAPES) for its partial financial support (Finance code 001) and to ICETI - Instituto Cesumar de Ciência, Tecnologia e Inovação.

\section{DECLARATION OF CONFLICTS OF INTERESTS}

The authors declare no conflict of interest. The founding sponsor had no role in the design of the study; in the collection, analyses, or interpretation of data; in the writing of the manuscript, and in the decision to publish the results.

\section{AUTHORS' CONTRIBUTIONS}

All authors were involved in the design of experiments, study, and data analysis. All authors critically revised the manuscript and approved of the final version.

\section{REFERENCES}

ADWAS, A. et al. Oxidative stress and antioxidant mechanisms in human body. Journal of Applied Biotechnology \& Bioengineering, v.6, n.1, p.43-47, 2019. Avaliable from: $\quad<$ https://www.researchgate.net/profile/Azab_Azab/ publication/331287732_Oxidative_stress_and_antioxidant mechanisms_in_human_body/links/5c9fd648a6fdccd460458f65/ Oxidative-stress-and-antioxidant-mechanisms-in-human-body. pdf $>$. Accessed: Feb. 03, 2020. doi: 10.15406/jabb.2019.06.00173.

ALAM, M. N. et al. Review on in vivo and in vitro methods evaluation of antioxidant activity. Saudi Pharmaceutical Journal, v.21, n.2, p.143-152, 2013. Avaliable from: <https:// www.sciencedirect.com/science/article/pii/S1319016412000357>. Accessed: Apr. 03, 2020. doi: 10.1016/j.jsps.2012.05.002.

ANTOLOVICH, M. et al. Methods for testing antioxidant activity. Analyst, v.127, n.1, p.183-198, 2002. Avaliable from: $<$ https://pubs.rsc.org/en/content/articlehtml/2002/an/b009171p $>$. Accessed: Feb. 06, 2020. doi: 10.1039/B009171P.

AWAH, F. M. et al. Free radical scavenging activity, phenolic contents and cytotoxicity of selected Nigerian medicinal plants. Food Chemistry, v.131, n.4, p.1279-1286, 2012. Avaliable from: $\quad<$ https://www.sciencedirect.com/science/article/abs/pii/ S0308814611013951>. Accessed: Feb. 24, 2020. doi: 10.1016/j. foodchem.2011.09.118.

AZAB, A. E. et al. Prevention of nephropathy by some natural sources of antioxidants. Yangtze Medicine, v.1, n.4, p.235-266, 2017. Avaliable from: <https://www.scirp.org/ pdf/YM_2017121216094513.pdf>. Accessed: Aug. 26, 2020. doi:10.4236/ym.2017.14023.

BATISTA, D. S. et al. Reference gene selection for qRT-PCR in Brazilian-ginseng [Pfaffia glomerata (Spreng.) Pedersen] as affected by various abiotic factors. Plant Cell, Tissue and Organ Culture (PCTOC), v.138, n.1, p.97-107, 2019. Avaliable from: 
$<$ https://link.springer.com/article/10.1007/s11240-019-01606-6>. Accessed: Apr. 12, 2020. doi: 10.1007/s11240-019-01606-6.

BRAND-WILLIAMS, W. et al. Use of a free radical method to evaluate antioxidant activity. LWT-Food science and Technology, v.28, n.1, p.25-30, 1995. Avaliable from: <https:// www.sciencedirect.com/science/article/pii/S0023643895800085>. Accessed: Oct. 06, 2019. doi: 10.1016/S0023-6438(95)80008-5.

CAMPOS, M. G. et al. Age-induced diminution of free radical scavenging capacity in bee pollens and the contribution of constituent flavonoids. Journal of Agricultural and Food Chemistry, v.51, n.3, p.742-745, 2003. Avaliable from: <https:// pubs.acs.org/doi/abs/10.1021/jf0206466>. Accessed: Apr. 15, 2020. doi: 10.1021/jf0206466.

DANIEL, J. F. S. et al. Free radical scavenging activity of Pfaffia glomerata (Spreng.) Pederson (Amaranthaceae). Indian Journal of Pharmacology, v.37, n.3, p.174, 2005. Avaliable from: <http:// www.ijp-online.com/article.asp?issn=0253-7613; year=2005; volu me $=37 ;$ issue $=3 ;$ spage $=174 ;$ epage $=178 ;$ aulast $=$ de $>$. Accessed: Oct . 16, 2019. doi: 10.4103/0253-7613.16215.

DINAN, Laurence. Phytoecdysteroids: biological aspects. Phytochemistry, v.57, n.3, p.325-339, 2001. Avaliable from $<$ https://www.sciencedirect.com/science/article/abs/pii/ S0031942201000784>. Accessed: Nov. 12, 2019. doi: 10.1016/ S0031-9422(01)00078-4.

FAWOLE, O. A. et al. Antibacterial, antioxidant and tyrosinaseinhibition activities of pomegranate fruit peel methanolic extract. BMC complementary and alternative medicine, v.12, n.1, p.200, 2012. Avaliable from: <https://link.springer.com/ article/10.1186/1472-6882-12-200>. Accessed: Jan. 22, 2020. doi: $10.1186 / 1472-6882-12-200$.

FELIPE, D. F. et al. Phytochemical analysis of Pfaffia glomerata inflorescences by LC-ESI-MS/MS. Molecules, v.19, n.10, p.15720-15734, 2014. Avaliable from: <https://www.mdpi. com/1420-3049/19/10/15720>. Accessed: Mar. 24, 2020. doi: 10.3390/molecules 191015720 .

FELIPE, S. H. S. et al. Accessions of Brazilian ginseng (Pfaffia glomerata) with contrasting anthocyanin content behave differently in growth, antioxidative defense, and 20-hydroxyecdysone levels under UV-B radiation. Protoplasma, v.256, n.6, p.1557-1571, 2019. Avaliable from: <https://link.springer.com/article/10.1007/ s00709-019-01400-3>. Accessed: Feb. 15, 2020. doi: 10.1007/ s00709-019-01400-3.

FERREIRA, A. et al. The in vitro screening for acetylcholinesterase inhibition and antioxidant activity of medicinal plants from Portugal. Journal of Ethnopharmacology, v.108, n.1, p.31-37, 2006. Avaliable from: <https://www.sciencedirect.com/science/ article/abs/pii/S0378874106002091>. Accessed: Mar. 02, 2020. doi: 10.1016/j.jep.2006.04.010

FESTUCCI-BUSELLI, R. A. et al. Biosynthesis and potential functions of the ecdysteroid 20-hydroxyecdysone-a review. Botany, v.86, n.9, p.978-987, 2008a. Avaliable from: <https:// www.nrcresearchpress.com/doi/abs/10.1139/B08-049\#.XvoaySh KjIU>. Accessed: Nov. 23, 2019. doi: 10.1139/B08-049.

FESTUCCI-BUSELLI, R. A. et al. Level and distribution of 20-hydroxyecdysone during Pfaffia glomerata development. Brazilian Journal of Plant Physiology, v.20, n.4, p.305-
311, 2008b. Avaliable from: <https:/www.mdpi.com/14203049/24/23/4212>. Accessed: Nov. 23, 2019. doi: 10.1590/S167704202008000400006 .

FIERASCU, R. C. et al. Recovery of natural antioxidants from agro-industrial side streams through advanced extraction techniques. Molecules, v.24, n.23, p.4212, 2019. Avaliable from: $\quad<$ https://www.scielo.br/scielo.php?pid=S167704202008000400006\&script $=$ sci arttext $>$. Accessed: Jan. 28, 2020. doi: $10.3390 /$ molecules 24234212

FREITAS, C. S. et al. Involvement of nitric oxide in the gastroprotective effects of an aqueous extract of Pfaffia glomerata (Spreng) Pedersen, Amaranthaceae, in rats. Life Sciences, v.74, n.9, p.1167-1179, 2004. Avaliable from: <https://pubmed.ncbi. nlm.nih.gov/14687657/>. Accessed: Jan. 28, 2020. doi: 10.1016/j. lfs.2003.08.003

HAN, Y. et al. Three new noroleanane-type triterpenes from the roots of Pfaffia glomerata. Journal of Asian natural products research, v. 20 , n.5, p.460-466, 2018. Avaliable from: <https:// www.tandfonline.com/doi/abs/10.1080/10286020.2017.1343820> . Accessed: Jan. 20, 2020. doi: 10.1080/10286020.2017.1343820.

IAREMA, L. et al. Photoautotrophic propagation of Brazilian ginseng [Pfaffia glomerata (Spreng.) Pedersen]. Plant Cell, Tissue and Organ Culture (PCTOC), v.110, n.2, p.227-238, 2012. Avaliable from: $<$ https://link.springer.com/article/10.1007/s11240012-0145-6>. Acessed: Aug. 24, 2020. doi: 10.1007/s11240-0120145-6.

JAYAPRAKASHA, G. K. et al. Antioxidant activity of grape seed (Vitis vinifera) extracts on peroxidation models in vitro. Food chemistry, v.73, n.3, p.285-290, 2001. Avaliable in: <https://www. sciencedirect.com/science/article/abs/pii/S0308814600002983>. Accessed: Apr. 14, 2020. doi:10.1016/S0308-8146(00)00298-3.

KOLEVA, I. I. et al. Screening of plant extracts for antioxidant activity: a comparative study on three testing methods. Phytochemical Analysis: An International Journal of Plant Chemical and Biochemical Techniques, v.13, n.1, p.8-17, 2002. Avaliable in: <https://onlinelibrary.wiley.com/doi/abs/10.1002/ pca.611>. Accessed: Jan. 24, 2020. doi: 10.1002/pca.611.

KUMARAN, A.; KARUNAKARAN, R. J. Antioxidant and free radical scavenging activity of an aqueous extract of Coleus aromaticus. Food chemistry, v.97, n.1, p.109-114, 2006. Avaliable from: $\quad<$ https://www.sciencedirect.com/science/article/abs/pii/ S0308814605002827>. Accessed: Nov. 12, 2019. doi: 10.1016/j. foodchem.2005.03.032.

KUSUMAWATI, I.; INDRAYANTO, G. Natural antioxidants in cosmetics. Studies in natural products chemistry. v.40, p.485505, 2013. Avaliable from: <https://www.sciencedirect.com/ science/article/pii/B9780444596031000151>. Accessed: Jan. 28, 2020. doi: 10.1016/B978-0-444-59603-1.00015-1.

LAFONT, R.; DINAN, L. Practical uses for ecdysteroids in mammals including humans: and update. Journal of insect science, v.3, n.1, p.1-30, 2003. Avaliable from: <https://www. ncbi.nlm.nih.gov/pmc/articles/PMC524647/>. Accessed: Mar. 12, 2020. doi: $10.1093 / \mathrm{jis} / 3.1 .7$.

LEAL, P. F. et al. Brazilian Ginseng extraction via LPSE and SFE: Global yields, extraction kinetics, chemical composition and antioxidant activity. The Journal of Supercritical Fluids, v.54, 
n.1, p.38-45, 2010. Avaliable from: <https://www.sciencedirect. com/science/article/abs/pii/S0896844610001129>. Accessed: Jan. 25, 2020. doi: 10.1016/j.supflu.2010.03.007.

LEITE, G. L. D. et al. Arthoropods associated to Pfaffia glomerata flowers in the Montes Claros-MG. Agropecuária Técnica, v.26, n.2, p.178-183, 2005. Avaliable from: $<$ https://www.researchgate.net/profile/Mayra_Pimenta/ publication/237768603_ARTROPODES_ASSOCIADOS_AS FLORES_DE_Pfaffia_glomerata_EM_MONTES_CLAR̄OSMG/links/582 d977c08ae004f74 bc $942 \mathrm{a} / \mathrm{ARTROPODES}-$ ASSOCIADOS-AS-FLORES-DE-Pfaffia-glomerata-EMMONTES-CLAROS-MG.pdf>. Accessed: Mar. 16, 2020.

MELO, E. A. et al. Antoxidant capacity of fruits. Revista Brasileira de Ciências Farmacêuticas, v.44, n.2, p.193-201, 2008. Avaliable from: <https://www.scielo.br/scielo.php?pid=s151693322008000200005\&script $=$ sci arttext $>$. Accessed: Jan. 15, 2020. doi:10.1590/S1516-93322008000200005.

NASCIMENTO, E. X. D. et al. Produção de biomassa de Pfaffia glomerata (Spreng.) Pedersen e Plantago major L. em cultivo solteiro e consorciado. Ciência e Agrotecnologia, v.31, n.3, p.724-730, 2007. Avaliable from: <https://www.scielo.br/scielo. php?script $=$ sci_arttext\&pid $=\mathrm{S} 141370542007000300019 \& \operatorname{lng}=$ pt\&nrm=iso\&t $\overline{\ln g=p t}>$. Accessed: Feb. 17, 2020. doi: 10.1590/ S1413-70542007000300019.

NSIMBA, R. Y. et al. Ecdysteroids act as inhibitors of calf skin collagenase and oxidative stress. Journal of Biochemical and Molecular Toxicology, v.22, n.4, p.240-250, 2008. Avaliable from: $<$ https://onlinelibrary.wiley.com/doi/abs/10.1002/jbt.20234>. Accessed: Feb. 02, 2020. doi: 10.1002/jbt.20234.

OLAJUYIGBE, O. O.; AFOLAYAN, A. J. Phenolic content and antioxidant property of the bark extracts of Ziziphus mucronata Willd. subsp. mucronata Willd. BMC Complementary and Alternative medicine, v.11, n.1, p.130, 2011. Avaliable from: $<$ https://link.springer.com/article/10.1186/1472-6882-11-130>. Accessed: Mar. 15, 2020. doi: 10.1186/1472-6882-11-130.

PRIETO, P. et al. Spectrophotometric quantitation of antioxidant capacity through the formation of a phosphomolybdenum complex: specific application to the determination of vitamin $\mathrm{E}$. Analytical Biochemistry, v.269, p.337-341, 1999. Avaliable from: <https://helvia.uco.es/bitstream/handle/10396/10963/ Spectrophotometric\%20Quantitation \%20\%281\%29. pdf? sequence $=1 \&$ isAllowed $=\mathrm{y}>$. Accessed: Nov. 12, 2020.

SALDANHA, C. W. et al. A CO 2-enriched atmosphere improves in vitro growth of Brazilian ginseng [Pfaffia glomerata (Spreng.) Pedersen]. In Vitro Cellular \& Developmental Biology-Plant, v.49, n.4, p.433-444, 2013. Avaliable from: <https://link.springer. com/article/10.1007\%2Fs11627-013-9529-5>. Accessed: Feb. 27, 2020. doi: 10.1007/s11627-013-9529-5.

SANTOS, A. K. L. et al. Antioxidant activity of five Brazilian plants used as traditional medicines and food in Brazil. Pharmacognosy magazine, v.6, n.24, p.335, 2010. Avaliable from: <https://www. ncbi.nlm.nih.gov/pmc/articles/PMC2992150/>. Accessed: Jan. 25, 2020 doi: 10.4103/0973-1296.71789.
SCHERER, R.; GODOY, H. T. Antioxidant activity index (AAI) by the 2, 2-diphenyl-1-picrylhydrazyl method. Food chemistry, v.112, n.3, p.654-658, 2009. Avaliable from: <https://www. sciencedirect.com/science/article/abs/pii/S0308814608007218>. Accessed: Nov. 12, 2019. doi: 10.1016/j.foodchem.2008.06.026.

SERRA, L. Z. et al. Quantification of $\beta$-ecdysone in differents parts of Pfaffia glomerata by HPLC. Revista Brasileira de Farmacognosia, v.22, n.6, p.1319-1354, 2012. Avaliable from: $\quad<$ https://www.scielo.br/scielo.php?pid=S0102695X2012000600021\&script $=$ sci arttext $>$. Accessed: Oct. 18, 2019. doi: 10.1590/S0102-695X2012005000114.

SHIOBARA, Y. et al. A nortriterpenoid, triterpenoids and ecdystereoids from Pfaffia glomerata. Phytochemistry, v.32, n.6, p.1527-1530, 1993. Avaliable from: <https:/www.sciencedirect. com/science/article/abs/pii/003194229385172N>. Accessed: Nov. 14, 20219. doi: 10.1016/0031-9422(93)85172-N.

SHOKRI, Z. et al. Thyroid diseases: Pathophysiology and new hopes in treatment with medicinal plants and natural antioxidants. International Journal of Green Pharmacy (IJGP), v.12, n.03, p.S473-482, 2018. Available from: <http://www.greenpharmacy. info/index.php/ijgp/article/view/2007>. Accessed: Feb. 14, 2020. doi: 10.22377/ijgp.v12i03.2007.

SIDDHURAJU, P. et al. Studies on the antioxidant activity of Indian Laburnum (Cassia fistula L.): a preliminary assessment of crude extracts from stem bark, leaves, flowers and fruit pulp. Food chemistry, v.79, n.1, p.61-67, 2002. Avaliable from: <https://www. sciencedirect.com/science/article/abs/pii/S0308814602001796>. Accessed: Mar. 15, 2020. doi: 10.1016/S0308-8146(02)00179-6.

TULMANN NETO, A et al. Analgesic and anti-inflammatory activity of a crude root extract of Pfaffia glomerata (Spreng) Pedersen. Journal of Ethnopharmacology, v.96, n.1-2, p.8791, 2005. Avaliable from: <https://pubmed.ncbi.nlm.nih. gov/15588654/>. Accessed: Jan. 25, 2020. doi: 10.1016/j. jep.2004.08.035.

TULMANN NETO, A. G. et al. Evaluation of the trypanocidal and leishmanicidal in vitro activity of the crude hydroalcoholic extract of Pfaffia glomerata (Amarathanceae) roots. Phytomedicine, v.11, n.7-8, p.662-665, 2004. Avaliable from: < https://pubmed.ncbi. nlm.nih.gov/15636182/>. Accessed: Jan. 25, 2020. doi: 10.1016/j. phymed.2003.06.005.

TUNG, Y. et al. Free radical-scavenging phytochemicals of hot water extracts of Acacia confusa leaves detected by an on-line screening method. Food Chemistry, v.115, n.3, p.1019-1024, 2009. Avaliable from: <https://www.sciencedirect.com/science/ article/abs/pii/S0308814609000697>. Accessed: Feb. 10, 2020. doi: 10.1016/j.foodchem.2009.01.026.

ZIMMER, A. R. et al. HPLC method for the determination of ecdysterone in extractive solution from Pfaffia glomerata. Journal of pharmaceutical and biomedical analysis, v.40, n.2, p.450-453, 2006. Avaliable from: <https://pubmed.ncbi.nlm. nih.gov/16125356/>. Accessed: Oct. 17, 2019. doi: 10.1016/j. jpba.2005.07.016. 